\title{
СИНТЕЗ ТРИКАРБОЦИАНИНОВ, МОДИФИЦИРОВАННЫХ АРОМАТИЧЕСКИМИ АМИНОКАРБОНОВЫМИ КИСЛОТАМИ, ОБРАЗУЮЩИХ КОМПЛЕКСЫ ПЕРЕХОДНЫХ МЕТАЛЛОВ, СВЯЗЫВАЮЩИЕ ОРГАНИЧЕСКИЕ ЭКСТРАЛИГАНДЫ
}

\section{А.О. Говтвань, И.А. Дорошенко, В.С. Орехов, М.К. Беклемишев,}

\section{Т.А. Подругина}

Химический факультет, Московский государственный университет им. М.В. Ломоносова, 119991, Российская Федерация, Москва, ГСП-1, Ленинские горы, д. 1, стр. 3.

DOI: 10.19163/MedChemRussia2021-2021-401

E-mail: kemkemalisa@mail.ru

Исследования в области использования флуоресцирующих веществ как хемочувствительных сенсоров ведутся уже продолжительное время. Введение заместителей разной природы в отдельные структурные фрагменты карбоцианинов позволяет делать направленную модификацию флуорофоров, создавая структуры с заданными свойствами для использования в различных областях химии, медицины и биологии [1].

В данной работе предложен подход к синтезу конформационно закрепленных трикарбоцианиновых красителей, модифицированных ароматическими аминокарбоновыми кислотами, способных вступать в комплексообразование с переходными металлами. На примере целевого красителя 1 зафиксировано комплексообразование с ионами $\mathrm{Cu}^{2+}$, приводящее к заметным изменениям спектров поглощения и флуоресценции. При проведении скринингового исследования 40 модельных аналитов для данного комплекса было зафиксировано изменение интенсивности полосы спектра флуоресценции для 5-гидрокситриптофана и тирамина, что позволяет рассматривать конъюгаты такого типа как потенциальные реагенты для обнаружения органических соединений, содержащих аминогруппу.

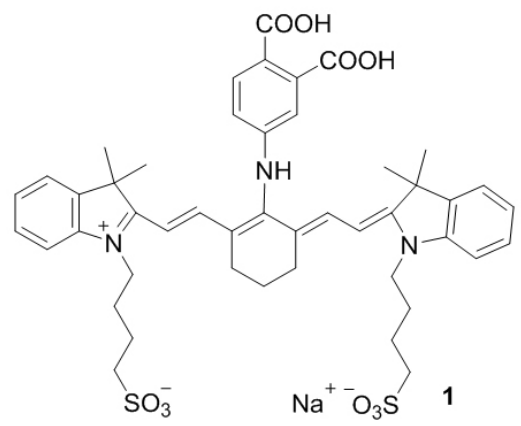

Работа выполнена при финансовой поддержке гранта РФФИ № 20-03-00334.

\section{Литература}

[1] C. Kar, Y. Shindo, K. Oka, S. Nishiyama, K. Suzukia, and D. Citterio, RSC Adv., 2017,7, 24970-24980.

$$
-401-
$$

